\title{
SPATIAL BEHAVIOR OF STUDENTS AND THEIR ROLE IN POLARIZED DEVELOPMENT: COMPARATIVE STUDIES OF YAROSLAVL OBLAST AND BAVARIA
}

\begin{abstract}
The article deals with the analysis of student educational migration and its role in origin of spatial contrasts at the territory of Russian early developed regions. In the paper ongoing processes are considered on the case of Yaroslavl oblast at the intra- and interregional levels and compared to processes abroad on the case of German federal state of Bavaria. The results are based on examination of official statistical data, surveys among students (disclosing their spatial behavior during the study and after degree completion) and expert interviews with university spokespersons. Migration bonds of Yaroslavl universities as well as space-time features of educational migration (average distances, time costs, transportation means) in Yaroslavl oblast and Bavaria are revealed. The study found that educational migration (together with other population mobility types) plays an important role in spatial polarization at the research territory due to importance of Yaroslavl as big educational centre for northern part of Non-Chernozem zone (Vologda, Arkhangelsk, Kostroma oblasts and Komi Republic). School-leavers from small cities and countryside come to the regional capital for bachelor's degree completion, next they try to go to Moscow, St. Petersburg or other largest cities not only to get masters' degree, but also in search of life conditions improvement. They want to change place of permanent residence and to have a career on perspective labor market.
\end{abstract}

KEY WORDS: educational migration, higher education institutions, early developed regions, spatial polarization, Yaroslavl oblast, Bavaria

CITATION: Alexandra V. Starikova (2019) Spatial Behavior Of Students And Their Role In Polarized Development: Comparative Studies Of Yaroslavl Oblast And Bavaria. Geography, Environment, Sustainability, Vol.12, No 2, p. 18-28

DOI-10.24057/2071-9388-2019-49

\section{INTRODUCTION}

In modern Russia polarization of space is closely related to the increase of spatial mobility and concentration of population into large and largest cities due to Russia's incomplete urbanization and attractiveness of large centers' labor markets for intraand interregional migrants (Nefedova and
Treivish 2019). Most often, administrative centers and their suburbs in Russian regions are the only centers of population growth against the background of steady population decline in the intraregional periphery (Mkrtchyan 2018). Such strengthening of socio-economic space polarization is especially characteristic of Non-Chernozem early developed regions, 
their small and medium-sized cities and countryside primarily suffering from intensive migration outflow of young people (Mkrtchyan 2019). School leavers aim to get into education institutions in large cities (including for living conditions improvement and adaptation to local labor market before a degree getting), so one can consider educational migration as one of urbanization stages. In such circumstances, relevance of educational migration researches and role of young people mobility and their spatial behavior in contrasts' intensification at intra- and interregional levels is increasing.

Literature review shows that educational migration compared to other migration types rarely becomes the main topic of researches, although many authors write about their role in migration processes' intensification and about urgency of such studies (Meusburger 1998, Katrovskiy 2003 etc.). Migrations with educational purposes are considering more often by sociologists, demographers and economists: mostly they highlight university students' mobility and such its aspects as demographic resources of educational migration (Pismennaya 2010), migration plans of school leavers and graduates (Varshavskaya and Chudinovskikh 2014), academic mobility (Kostina 2014). Researches abroad also pay special attention to academic mobility patterns (Cornet 2015), among other often discussed topics are international migration of students and its geographical structure (Kelo et al. 2006).

According to Katrovskiy (2003) educational migration analysis need to be conducted from the standpoint of geographical approach due to geographical synthesis potential in the problems' generalization in the area of territorial organization of education. Consideration of the spatiotemporal characteristics, territorial structure and scale of migration are of top priority for early developed regions because it allows to determine the significance of educational migration for their socioeconomic development.
The process of educational migration is studied by Russian authors in the context of international migration, special attention is paid to the prospects of Russian universities in teaching foreigners and their adaptation to the new environment (Dementieva and Giniyatova 2012, Study migration from CIS and Baltic countries 2012). Internal educational migration is analysed by cases of separate universities and rarely by cases of regions (Voronezh and Tomsk oblasts, North Caucasus). There are also series of works dedicated to youth migration including school leavers and students (Kashnitsky, Mkrtchyan and Leshukov 2016; Mkrtchyan 2017, 2019; etc.). Special place among the publications is occupied by the fundamental study of German geographer P. Meusburger (1998) devoted to geography of knowledge, science and education (including issues related to educational mobility).

Educational migration across Bavaria borders was considered by German researches in the context of economic and social state of students in old and in new federal states of Germany (Middendorff et al. 2013). Internal migration of students was examined by R. Rödel (2010) based on data about origin of first-year students in local universities.

The urgency of educational migration studies is increasing also due to the process of strengthening the role of universities as "engine" of territorial development and their influence on local labor markets (Katrovskiy 2003). In the current research author aimed at analysing of spatiotemporal features of student educational migration and their behavior within the time geography framework. This scientific direction has appeared in the Lund School of T. Hägerstrand in the 1960-70s. (Hägerstrand 1970). At the heart of time geography understanding of space-time organization of people's activities lies, when individuals are forced to move constantly within the framework of a daily, weekly or annual cycle: between home, work, places of rest, study, etc. As distinct from other works of Russian authors in the research the ongoing processes (on the case of Yaroslavl 
oblasts) are considered at the intra- and interregional levels and compared to processes in foreign countries (on the case of Bavaria) in order to understand if foreign realities will be prospects for early developed regions evolution.

\section{MATERIALS AND METHODS}

In Russian statistical sources intra- and interregional migration links (including commuters flows) cannot be directly traced that's why their use is possible only with some restrictions: it is considered in detail by Kashnitsky, Mkrtchyan and Leshukov (2016). Some higher education institutions in their yearbooks and other documents provide information about non-resident students, but it is not enough for detailed analysis. Under such conditions, the main data source about educational migration is surveys of students and expert interviews with university spokespersons: it makes possible to identify the features of migration processes at regional level, flows structure and migration behaviour of students.

As case for the research Yaroslavl oblasts was selected. It is one of the most industrially developed regions in Central Russia. Here there are large-scale facilities (including high-tech ones), forming the demand for highly skilled workers. Such specialists are educated in numerous local higher education institutions that attract both local and non-resident (from other Russian regions and from abroad) students. In the base of the research is a survey of students (190 people in 2018) of three universities in Yaroslavl: P.G. Demidov Yaroslavl State University, Yaroslavl State Pedagogical University named after K.D. Ushinsky and Yaroslavl State Medical University (such set of education institutions is associated with role of classical, medical and pedagogical universities for regional development). The survey was carried out in the form of a questionnaire, respondents answered questions from three blocks: about their social and financial situation, life in the city and plans for the future. In the same period interviews with experts were conducted. Also, data on the residence of part-time students (1509 people) of the Yaroslavl branch of Academy of labour and social relations (head institution - in Moscow) were analysed.

As case abroad German federal state of Bavaria was chosen. Among other federal states it is distinguished by low crossborder educational mobility and at the same time very high mobility in the Bavaria territory (Starikova 2017). The share of commuters among students is here even higher than among workers (Böhme 2007). The main feature of educational migration bonds in Bavaria are their regionality (Starikova 2017) that largely is in line with the current trends to higher education regionalization (Katrovskiy 2003) going in our country. On the other hand, in Bavaria there is developed transport infrastructure, tax benefits and state support to students as good basis for such migration type. Data about educational migration has obtained from different official statistical sources, the primary of them are regularly published population microcensus results (Erwerbstätige sowie Schüler und Studierende nach Pendlereigenschaften in Bayern... 2017). Some indices for general presentation of Yaroslavl oblast and Bavaria are given in Table 1.

\section{RESULTS AND DISCUSSION}

Since the 1990s. importance of migration for Russian early developed regions is increasing due to its possibility redistributing human capital and smoothing down negative effects of natural population decline and aging. In the Yaroslavl oblast today the processes of economic and social desertification are underway in the countryside and peripheral areas. In some years net migration rate compensated here for up to $20 \%$ of the natural decline of population (over 15\% in 2017), but nowadays it is focused on city of Yaroslavl and the surrounding Yaroslavl district (here locates the main part of regional center's suburbs). In such situation issues of youth people mobility (including their spatial behavior during educational migration) come to the fore in the light of local problems solving. 
Table 1. Area, population and students' number of Yaroslavl oblast and Bavaria

\begin{tabular}{|c|c|c|}
\hline Index & Yaroslavl oblast & Bavaria \\
\hline Land area (sq. km) & 36.2 & 70.5 \\
\hline $\begin{array}{c}\text { Population (thousands, 2018) } \\
\text { Administrative center or capital (Population, } \\
\text { thousands, 2018) }\end{array}$ & Yaroslavl (608.7) & München (1539.3) \\
\hline $\begin{array}{c}\text { Number of students (thousands, 2017-18 } \\
\text { academic year) }\end{array}$ & 31.3 & 388.9 \\
\hline $\begin{array}{c}\text { Number of students per 10000 inhabitants (2018) } \\
\text { Numb.9. }\end{array}$ & 247 & 299 \\
\hline
\end{tabular}

Yaroslavl as one of the largest cities of NonChernozem zone (its population exceeds 600 thousand people) congregates young people not only from its region, but also from remote areas (for example, the distance between Yaroslavl and Vorkuta is over $3000 \mathrm{~km}$, between Yaroslavl and Arkhangelsk is almost 1000 km). Among main attractors for young people are local higher education institutions. Yaroslavl oblast in the Central Federal District ranks $4^{\text {th }}$ (after Moscow, Moscow oblast and Voronezh oblast) in terms of higher education institutions number (24 at the beginning of the 2017-18 academic year) and $7^{\text {th }}$ (after Moscow, Smolensk, Kaluga, Bryansk, Vladimir and Voronezh oblasts) by the number of branches. Most of higher education institutions locate in Yaroslavl (over $90 \%$ of students in the region study here); there are also higher education institutions in Rybinsk (over 9\%) and Tutaev. At the beginning of the 2017-18 academic year the total number of students in Yaroslavl oblast was 31.3 thousand people. It is important to note that Yaroslavl attractiveness determines due not only to its own attractors: proximity to Moscow is of particular importance (Yaroslavl is only $300 \mathrm{~km}$ away from it). For many young people Russia's capital is viewed as the final goal of their migratory movements chain and Yaroslavl is only a springboard to its achievement.

The overwhelming majority of students are Russians (97.2\% in 2017) with predominating of the Yaroslavl oblast residents (87.7\%; more than half of them are from administrative centre $-56.4 \%$, there are also residents of Rybinsk - about 7.0\%, Rostov - 4.5\%, Pereslavl-Zalessky - 2.5\%, Uglich - 2.1\% and Danilov - 2.0\%). More than $20 \%$ of the students are from rural areas. A small number of foreign students represent a few dozen countries, about 44.5\% originate from Tajikistan and else $10.9 \%$ from Turkmenistan. The most popular educational programs for foreigners are offered in State Aviation Technical University named after P.A. Solovyov (in Rybinsk and Tutaev), agricultural academy, technical and medical universities (all in Yaroslavl).

The territorial structure of interregional educational migrations was determined using the data about residence place of Academy of Labor and Social Relations'parttime students. Comparison of the results with the survey among full-time students of other institutions and interviews with spokespersons allowed to reveal main migrant-supplying regions. Traditionally strong migration ties are with Yaroslavl universities in the cities and districts of the Arkhangelsk oblast (35.5\% of interregional educational migrants, primarily from Arkhangelsk, Velsk, Velskiy and Plesetsky districts, Nyandoma). Significant migrants' part is supplied by neighbouring Kostroma (almost 12\%; from different areas but rarely from the administrative centre), Vologda (almost 10\%, mainly from Cherepovets and Vologda), Ivanovo (about 5\%) oblasts and Komi Republic (approx. 6.5\%). About $12 \%$ are residents of the Moscow capital region (Moscow and Moscow oblast), who are attracted by the education costs in the branch of Academy of Labor and Social 
Relations compared to the head university. The results of the survey and expert interviews let to talk about Yaroslavl role as an important educational centre in Non-Chernozem zone (especially for Vologda, Arkhangelsk, Kostroma oblasts and Komi Republic). Thus, by the share of university entrants to the architectural and construction faculty of Yaroslavl State Technical University in 2017 the same regions stood out (Vologda - 10\% of university entrants, Kostroma - 10-11\%, Arkhangelsk - less than 10\%, Komi - about $5 \%$, a little less - from Ivanovo, Moscow and Tver oblast).

Migration ties are actively maintaining within the framework of cooperation in the field of personnel training programs between technical and vocational education organizations (primarily, these are pedagogical and medical colleges) and universities. For example, Association of continuing professional education at the head of the Yaroslavl State Pedagogical University operates for several decades and units 22 pedagogical colleges from the Yaroslavl oblast, all neighboring regions, as well as from the Arkhangelsk and Kirov oblasts and Komi Republic.

The structure of migration links is also determined by the position of Yaroslavl on the Northern Railway, which direction corresponds to the main migrantsupplying regions. For Yaroslavl State Medical University, both the connections formed in the Soviet era due to process of university location (they trained specialists for certain regions, institutions in Yaroslavl served the northern part of European Russia) and modern agreements on the creation of joint departments for targeted training of specialists (today there are two such departments - in cities Vologda and Kostroma). Regions and cities, which are the main suppliers of educational migrants, also provide Yaroslavl oblast with commuters and approximately in the same ratio (Kondakova 2017), which indicates the necessity and prospects of educational migration studies.
More than $1 / 3$ of the respondents indicated that after study completion they want to stay in Yaroslavl (to live and work, less often - to study) (Fig. 1): most of them are residents of other Russian regions (57\%). Among reasons that push students from neighboring regions to stay in Yaroslavl, experts denote higher incomes, climate, proximity to Moscow, relatives settled here or nearby. Significant share of the respondents (1/5) associate their future with life in another major city: they try to get into Moscow or St. Petersburg, less popular are cities of the Russian South (Krasnodar, Sochi, Rostov-on-Don) and administrative centers (like Kazan, Ryazan, Vologda).

Along with the territorial structure of educational migration, spatio-temporal features of this population mobility type were analyzed. In contrast to other Russian researches educational migration is considering compared to processes abroad (by the example of Bavaria).

Non-resident students make trips to their places of permanent residence during the year (Fig. 2): over $75 \%$ of them doing it with a certain rhythmicity, the other visit home occasionally (1-2 times a month, halfyearly, in summer, etc.).

High trips'frequency is peculiar to students permanently living in the Yaroslavl oblast. They move between places of residence and studying 1-2 times a week (and more often) and spend weekends at home (so more than half of intraregional migrants do). Students from other regions have a chance to visit their families mainly for weekends (respondents from Ivanovo, Vladimir, Kostroma, Vologda, Arkhangelsk oblasts and Komi Republic say about such practice) or holidays. The share of students returning home for the weekends decreases with the growth of the distance between their settlement and city of Yaroslavl (of course, transportation, direct routes' presence and need to make connections could matter), at the same time the share of non-residents spending holidays at home increases. 


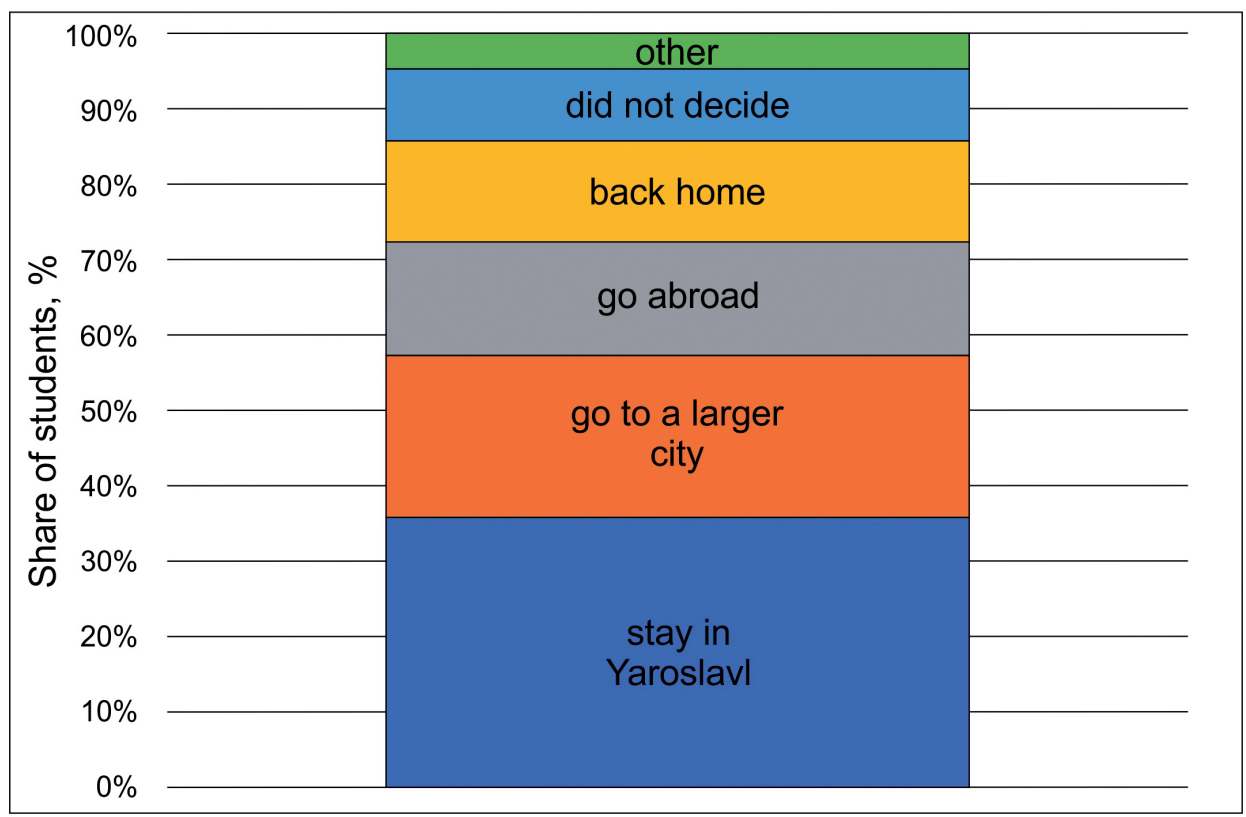

Fig. 1. Distribution of respondents' answers to the question «What are you going to do after you graduate?»

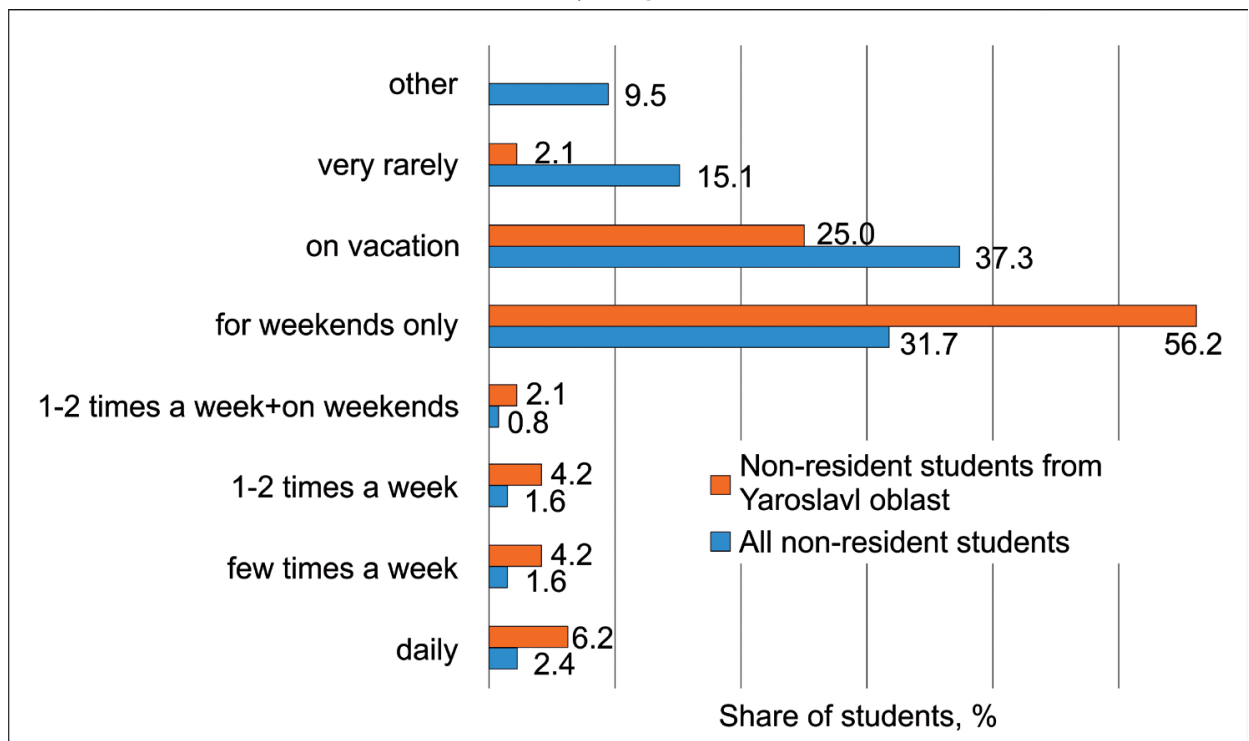

Fig. 2. The frequency of home visiting by non-resident students, 2018

Time in educational migration processes plays an important role: it depends on both distance (between house and education institutions) and choice of transportation means. Nearly half of the respondents use rail transport, most of them are non-Yaroslavl oblast residents. More than a quarter of the respondents use intercity buses. These are students from the Yaroslavl oblast and neighboring regions. Another quarter gets to their homes by private cars or hitchhike. The mobility of students is largely influenced by their financial capacities (trip costs is often significant for family budget), so young people prefer to visit their homes rarely or to look for a cheaper transport (car-pooling and services like BlaBlaCar; long-distance trip by train instead of flight, etc.). 
If we talk about Germany one can suppose that students' time costs on the trip to the universityare less than in Russia (considering high level of transport accessibility on its territory). It is more profitable for them to travel every day rather than to move closer to their university or other high school due to many municipalities impose taxes on those who rent accommodation here, so students bear additional costs. Available German statistics allow us to look at the spatio-temporal features of daily educational migration and accordingly to compare it with processes in Russia.

Both in the Yaroslavl oblast and in the federal state of Bavaria, universities are usually located in large cities, and the number of daily trips participants decline as the distance to education institution increases. However, there is a clear difference in the distribution of migration participants shares depending on the distance (Fig. 3). Differences in the average radiuses of trips are pronounced: in Yaroslavl oblast radiuses of one-way trip are almost two times shorter than in Bavaria $(11.8 \mathrm{~km}$ and 22.3 $\mathrm{km}$, respectively; radiuses are calculated as the weighted average according to Fig. 3).

In case of Yaroslavl oblast direct dependence of commuters share among students on the trip distance is revealed: the greater distance between home and university, the less young people overcoming it. Most of the respondents live near their education institution, for more than $67 \%$ of them one-way trip is less than $10 \mathrm{~km}$, time costs are also small (less than half an hour). The second group is formed by students (a little more than 1/4 of the respondents) traveling $10-25 \mathrm{~km}$ daily, the share of the rest is slightly more than $6 \%$. This distribution may be caused due to many of respondents have an opportunity to live near the university in dormitories (1/3 of students for whom the distance of commuting is less than $10 \mathrm{~km}$ ) or renting apartments nearby (1/4). In Bavaria, the share of young people living in the area of their universities is also high, but the proportion of students living at a sizeable distance (more than $25 \mathrm{~km}$ ) is much higher. Shares of commuters, covering distances over $10 \mathrm{~km}$, decline slightly with distances increasing, and those who travel over 50 $\mathrm{km}$ become even more.

These indicators reflect differences in the level of population spatial mobility due to several factors. In Bavaria transport accessibility of universities is significantly higher, besides local authorities provide financial support to students ready to make long trips to places of their study. But unlike Russia it is harder for students to get a room in university campuses (always there is a big queue here). In Russian conditions, providing of non-residents with a dormitory is a traditional practice, at the same time it is much more difficult to get to the university by public transport from remote places and to offset financial costs by scholarship and part-time job.

Regarding to time costs, for Russian and German students the average travel time to the place of study practically coincides

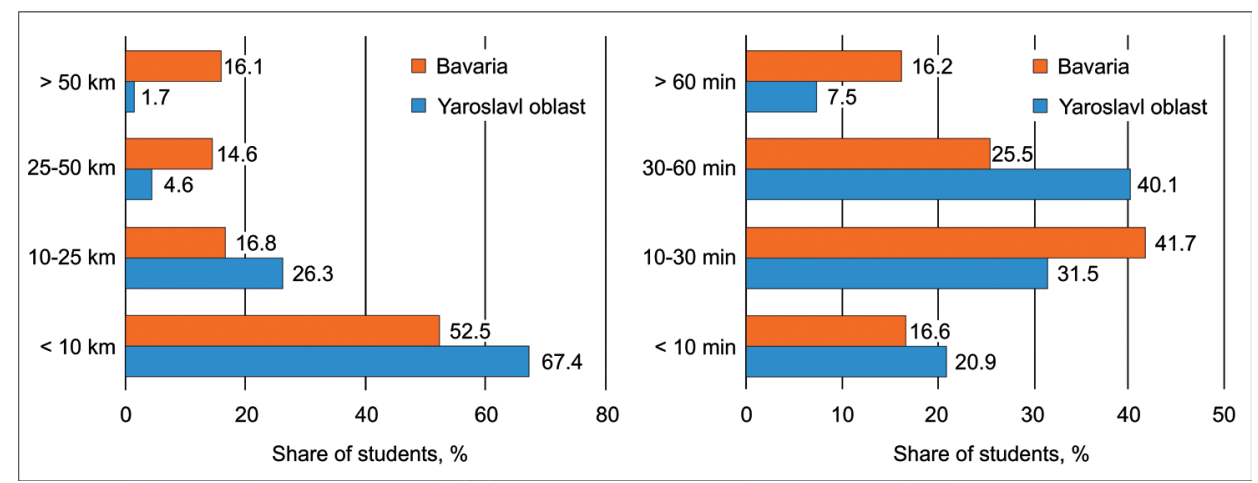

Fig. 3. Trip distances (left) and time costs (right) during students daily educational migration in Yaroslavl Oblast (2018) and Bavaria (2016) 
(31.6 and 33.8 minutes, respectively; obtained according to Fig. 3 as the weighted average). Nevertheless, among students of Yaroslavl universities, the share of people traveling 30-60 minutes on their trip is especially big (and significantly more than in Bavaria). This time is spending to move within the city, and not on longdistance interregional travels. In Bavaria, a similar proportion of students need for 10-30 minutes (both on intra-city trips and on moving from the suburbs); those who ready to spend more than an hour to reach the university are much more (primarily due to the developed transport infrastructure). In the city students of Yaroslavl universities use bus and trolleybus routes, rarely - taxis: over $57 \%$ of respondents gives preference to public transport (Fig. 4). It is bounded with the fact that most of respondents (including non-residents) live in Yaroslavl during the study period and doesn't have a need to go to the city daily. Respondents (2.7\%) leaving regional center for holidays and weekends prefer suburban transport. Personal cars due to financial costs are using only $13.3 \%$ of students (almost 2 times less than in Bavaria). Almost a quarter of respondents goes on foot by the route to the university or its significant part. Bavarian students have no marked preferences. Urban public transport isn't so popular (it is chosen by just over 30\%), although it is possible to use specially organized routes. The share of students using private cars (due to higher standard of living) and suburban transport (because of higher value of average commuting radiuses) is naturally high. In Bavaria there are a lot of cyclists among commuters $(17.1 \%$ in the federal state versus 3.1\% in the Yaroslavl oblast). It connects not only with the Germans' thrift, healthy lifestyle practicing and preservation of the environment, but also with mild natural conditions (one can ride a bike throughout the year, including winter), as well as the widespread infrastructure for cyclists (in our country it isn't enough).

\section{CONCLUSIONS}

The socio-demographic situation in Yaroslavl oblast is in line with problems of other European Russia early developed regions. It relates with population decline and migration outflow of working-age residents from small cities and rural areas into large center and its suburbs: in other words, into Yaroslavl and its district. Educational migration together with other migration types plays significant role in intensification of spatial contrasts at the intra- and interregional levels due

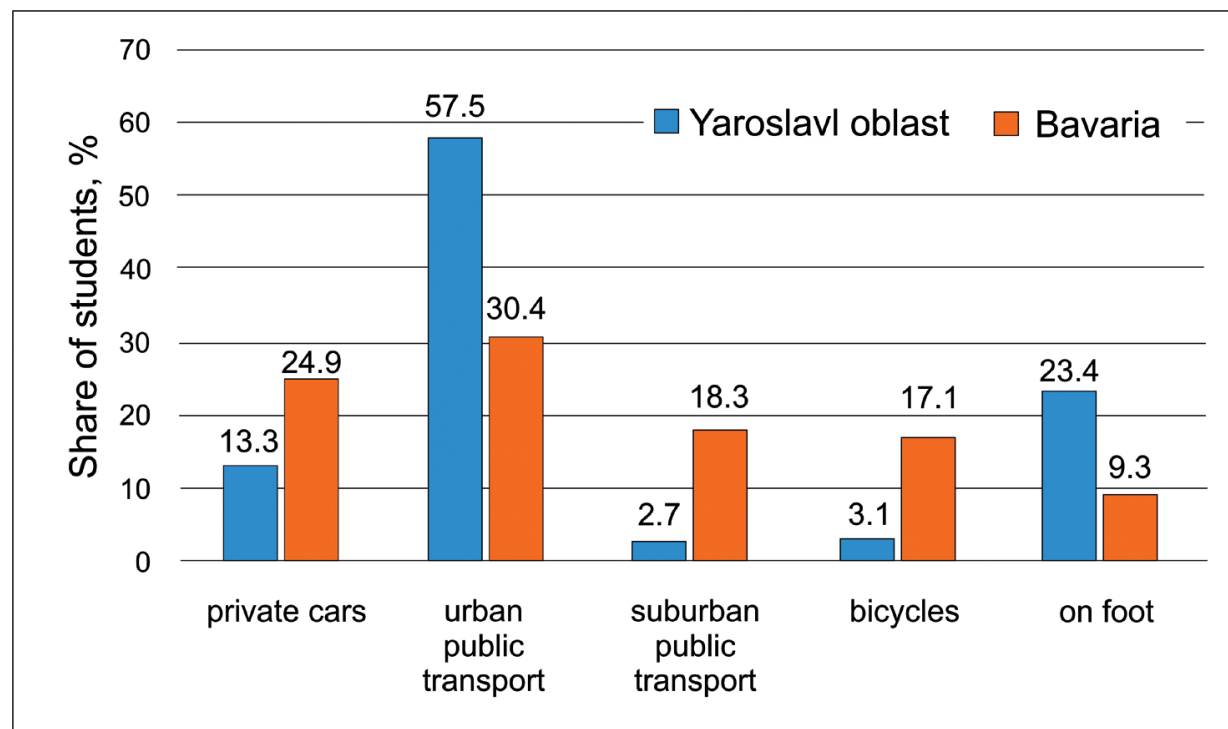

Fig. 4. Main transportation means for daily trips from home to university in Yaroslavl Oblast (2018) and Bavaria (2016) 
to importance of Yaroslavl as educational center for northern part of Central Russia and often as a springboard for further migration to Moscow.

Arkhangelsk, Vologda and Kostroma oblasts as well as Komi Republic are the main interregional educational migrantsuppliers for Yaroslavl and its universities. Speaking about intraregional migration one can note that approximately half of Yaroslavl students are the dwellers of this center. The proportion of residents from other cities of its region is also large, 1/5 of students comes from the countryside. Spatial behavior of these young people is predominantly focused on large cities. If school-leavers from small cities and rural settlements usually go to the regional center, after completion of a bachelor's degree in Yaroslavl they strive to continue education in largest centers - Moscow and rarely in St. Petersburg (less often to move in capitals of other regions or southern Russia's cities). The main goal of graduates isn't only to get masters' degree, but also to change place of permanent residence with improving economic, social and living conditions compared to those in their own settlements.

Student spatial behavior during educational migration is characterized by different rhythm. The high trips' frequency (usually 1-2 times a week) is revealed for the residents of Yaroslavl oblast. With the growth of remoteness between places of residence and study and depending on the transport accessibility share of students going home for the weekends decreases, at the same time the share of those who spending at home only holidays increases. The average radiuses of daily educational migration in the Yaroslavl oblast is half as much as the same indicator for Bavaria with close indicator of average time per trip. This is because most of Yaroslavl students live in a dormitory near universities and don't need to go from remote areas with low transport accessibility. Among Bavarian students the share of long-distance commuters is several times higher than for Yaroslavl students because of developed infrastructure, state financial support for such migrants and the high cost of apartments renting near universities. At Russian students the most popular transportation means are trains (for young people living outside the region), buses (for students from the Yaroslavl oblast and neighboring regions) and private cars; for daily educational migration they prefer urban public transport. Bavarian students have no pronounced priorities, but among them there are much more car enthusiasts, passengers of suburban transport and cyclists. The comparison shows that in early developed regions of Non-Chernozemzone educational migration (students' spatial behavior included) is a factor of spatial contrasts' intensification under continuing urbanization while in Bavaria this type of return migration increases uniformity of human activity distribution on its territory under suburbanization and deurbanization processes. Evolution of early developed regions in line with German experience is attractive, but it is concerned primarily with solving their typical infrastructural and economic problems, improvement of living standards and creating of selfrealization opportunities for youth people in small cities and rural areas.

\section{ACKNOWLEDGEMENTS}

The study was financially supported by the Russian Scientific Foundation (project N 1917- 00174 "Early developed regions under socio-economic polarization and shrinkage of active space in European Russia" for the Institute of Geography, Russian Academy of Sciences). 


\section{REFERENCES}

Böhme M. (2007). Ausbildungsmarkt und Ausbildungsmobilität in Bayern. IAB regional. IAB Bayern. Nr. 01.

Cornet F. (2015). Student Mobility in European Higher Education. J. Higher Education and Lifelong Learning, №22, pp. 57-66.

Dementieva S. and Giniyatova E. (2012). Educational Migration to the Tomsk Polytechnic University: Mechanisms and Practices of Effective Adaptation. Bulletin of the Tomsk Polytechnic University. Economy. Philosophy, Sociology and Cultural Studies, History, vol. 321, №6, pp. 187-190. (in Russian).

Erwerbstätige sowie Schüler und Studierende nach Pendlereigenschaften in Bayern 2016. Statistische Berichte. Ergebnisse der 1\%-Mikrozensuserhebung 2016, (2017). Bayerisches Landesamt für Statistik, Fürth.

Hägerstrand T. (1970). What about people in regional science? Papers of the Regional Science Association, vol. 24, pp. 7-21.

Kashnitsky l., Mkrtchyan N. and Leshukov O. (2016). Interregional Youth Migration in Russia: a Comprehensive Analysis of Demographic Statistical Data. Educational Studies, №3, pp. 169-203.

Katrovskiy A. (2003). Territorial Organization of Higher Education in Russia: Monograph. Smolensk: Oikumena. (in Russian).

Kelo M., Teichler U. and Wächter B. (eds.) (2006). EURODATA - Student mobility in European higher education. Bonn: Lemmens Verlags- \& Mediengesellschaft.

Kondakova T. (2017). Features of the Modern Socio-Economic Development of Rural Areas in the Yaroslavl Oblast. Geography and Ecology in the school of the XXI century, №1, pp. 19-29. (in Russian).

Kostina E. (2014). Academic Mobility of Students of Higher Education in Russia: a Crosscultural Approach. Philosophy of education, №6(57), pp. 64-76. (in Russian).

Meusburger P. (1998). Bildungsgeographie: Wissen und Ausbildung in der räumlichen Dimension. Heidelberg, Spektrum Akademischer Verlag.

MiddendorffE., Apolinarski B., Poskowsky J., Kandulla M., Netz N. (2013). Die wirtschaftliche und soziale Lage der Studierenden in Deutschland 2012. 20. Sozialerhebung des Deutschen Studentenwerks, durchgeführt durch das HIS-Institut für Hochschulforschung. Bonn/Berlin.

Mkrtchyan N. (2017). The youth migration from small towns in Russia. Monitoring of Public Opinion: Economic and Social Changes, №1, pp. 225-242.

Mkrtchyan N. (2018). Regional Capitals and Their Suburbs in Russia: Net Migration Patterns. Bulletin of the Russian Academy of Sciences. Geography, №6, pp. 26-38. (in Russian).

Mkrtchyan N. (2019). Migration in Rural Areas of Russia: Territorial Differences. Population and Economics, №3(1), pp. 39-51.

Nefedova T., Treivish A. (2019). Urbanization and Seasonal Deurbanization in Modern Russia. Regional Research of Russia, vol. 9, №1, pp. 1-11. 
Pismennaya E. (2010). Educational Migration to Russia: Role in Socio-Economic and Demographic Development. Bulletin of higher education institutions. Sociology. Economy. Politics, №1, pp. 76-78. (in Russian).

Rödel R. (2010). Zugereiste oder Einheimische? Die Herkunft von Erstsemestern an bayerischen Hochschulen. Bayern in Zahlen, №12, pp. 561-567.

Starikova A. (2017). Educational Migration in Bavaria: Features and Role in the Formation of the Migration Patterns in the Region. Scholarly Papers of V.I. Vernadsky Crimean Federal University. Geography, Geology, vol. 3, №2, pp. 173-185. (in Russian with English summary).

Study migration from CIS and Baltic countries: potential and prospects for Russia (2012). Moscow: Fund «Eurasia Heritage». (in Russian).

Varshavskaya E. and Chudinovskikh O. (2014). Migration plans of graduates in regional universities of Russia. Herald of the Lomonosov Moscow State University. Geography, №3, pp. 36-58. (in Russian).

Received on April 28 ${ }^{\text {th }}, 2019$

Accepted on May $17^{\text {th }}, 2019$ 